\title{
Analysis of Necessity of the Acceleration of Solid Waste Management in China in "Twelfth Five-Year Plan" Period and Suggestions
}

\author{
Li-Ping ZHOU ${ }^{1,2, a, *}$ \\ ${ }^{1}$ Huazhong University of Science and Technology, Wuhan, P. R. China \\ ${ }^{2}$ Jiyuan Vocational and Technical College, Henan, P. R. China \\ ajyzlp638@163.com \\ ${ }^{*}$ Corresponding author
}

Keywords: Solid Waste, Hazardous Waste, Waste Management, Pollution Control, "Twelfth Five-Year Plan".

\begin{abstract}
This paper presents the basic concept of waste and principal theory of hazardous waste management. While elaborating serious damages caused by solid waste, the paper also introduces relevant management policies of the US concerning hazardous waste. After the analysis of the current state of solid waste management in China, the paper proposes to accelerate the improvement of solid waste management system in our country. We are expecting a domestically effective solid waste management and an avoidance from similar pollution events overseas.
\end{abstract}

\section{Introduction}

Along with economic development, people's ability to make use of nature and remake nature has largely enhanced. While enjoying material well-being granted by nature, we are disturbing the balance of it by excessive discharge and unreasonable use. Waste discharge includes solid waste, liquid pollutants and gas emission.

In recent years, because of the discovery of toxic substance emission, the government has issued official order to keep people away from residences and markets. People are shuddered by the potential danger of solid waste. Reports about strange odor sent out from buildings' basements, polluted water supply or queer disease that can't be diagnosed by doctors are here and there. All these phenomena bear close contact with unexpected waste leakage and unclear waste buried deeply years ago.

Take the US as an example, many of its once bustling communities, such as the beach of Love Canal in New York, Missouri and so on, turn into ruins under the influence of toxic waste. These events

\section{Definition of Solid Waste}

Solid waste is the so-called rubbish. It is the ordure of human metabolism and the leftovers of the consumption, including living garbage, production waste, medical waste, etc. Hazardous Waste refers to all the harmful substance or waste that poses serious substantial or potential threats to public health or the environment. Those substances that be viewed as hazardous solid waste vary widely. Therefore, solid waste can be divided into sub on the basis of their hazardous composition, which includes, for instance, acid and alkali, heavy metal, easy reaction material, solvent, pesticide and synthetic chemicals.

For example, used battery is one of the commonest and most typical hazardous waste (however, old batteries used by citizens are not included in the control area). One button battery will make 600 tons of water undrinkable (which is the total drinking water of a person throughout his life). Take 
discarded cell phone for another example. Americans abandon approximately 0.13 billion ones annually, which will produce 65 thousand tons of toxic metal or other refuse harmful to human health. In 2001, the US has produced 0.2292 tons of solid waste, i.e. averagely 4.4 pounds per person per day. As estimated by EPA, among 0.25 billion tons of waste produced annually-one ton per person per day on average-only about $10 \%$ can be handled safely.

\section{Harmfulness of Solid Waste}

Generally speaking, it is the characteristics that are beneficial to the manufacturing that are harmful to the society after converging into the waste flow. Waste flow means a series of activities that begin with waste production followed by waste transportation, store and management. Once hazardous substances join in the waste flow, excessive production and unreasonable management of them will cause physical and environmental damage.

Love Canal waste pollution event of 1977, which is world famous throughout the history of world environmental pollution, was actually caused by chemical solid waste. In 1978, New York urged 1000 families to leave their houses and another 240 to immediately evacuate from their homes. All the people are citizens of Love Canal community near Niagara Falls. This community was once a large dumping place for wastes 30 years ago, which later, finally, was declared disaster area by President Carter.

Another case shows that in 1982, people living on the beach of Times in Missouri were informed that the underground water and soil of their community contain a high level of dangerous pyronine. It is the result of polluted tar used 11 years ago and as a result, all the citizens there had to be evacuated from the beach. Pyronine is one of the most toxic chemical well known in the scientific field. In a draft report proposed by EPA in September 1994, which was open to public comments, pyronine is listed as most dangerous to human health. Its impact to public health can be compared to that of DD in 1960s.

The pollution source in all the above events is solid waste disposed years ago. The danger of solid waste is not deliberately exaggerated and should draw enough attention from the whole society and state policy makers. If disposed improperly, toxic or harmful substances, such as chemical substances, Pathogenic microbes and so on, in solid waste, hazardous waste in particular, will enter into the ecosystem through air, soil and surface or underground water system, thus causing chemical type pollution or pathogen size pollution. It will be harmful to human body, destroy ecosystem and lead to irreversible ecological change. As to through what particular way does it lead us to fall ill, it depends on the physical, chemical and biological properties of the solid waste itself, which also bears close relation to the water quality and hydrology. For instance, some will join in the air directly through evaporation, while more enter into human body through touching, eating polluted food or drinking polluted water. In conclusion, if not handled properly and taken full use of, solid waste will become new pollution source, which goes against the targets for saving energy and reducing emissions and does harm to our generation and offspring. It is an extreme damage not only to our nation but to the whole world. Therefore, we should pay enough attention to the harmfulness of solid waste. It is a task that is too urgent to ignore and should draw world's attention and measurement. 


\section{Current State of Solid Waste Management in China}

China has already carried out some management system concerning hazardous solid waste. In 2005, we have issued the new Law on Prevention and Control of Environmental Pollution by Solid Waste. A series of systems have been built up to control and prevent solid waste pollution, which include solid waste report and register system, dangerous waste operating permit and import waste approval system.

However, there are still issues in this regard in our country. Firstly, the centralized treatment rate is low. For instance, in the field of garbage collection, we just put signs saying "Recyclable" or "Unrecyclable" on dustbins, which is not forcible and without supervised. There is no particular independent department to recycle old batteries, too. Secondly, it is difficult to measure and calculate the figures of household waste and manufacture waste as well as the degree of environmental pollution. The existing environment monitoring index only contains figures of air and water quality, which bears no connection with garbage emission and pollution. Thirdly, we haven't pay enough attention to the damage that may be caused by solid waste and the funds in this aspect should be increased. China began its research on solid waste management technique ever since we were in the period of the eighth five years. During the ninth five years, what we have found from literature collection didn't show many hints pointing to solid waste. Next five years saw a limited fund for this research. In the period of the $11^{\text {th }}$ five years, nation's environmental protection department has explicitly made the management on city waste and dangerous waste major projects. In order to improve city environment, intensify the management on handling fee of city solid waste and boost healthy development of city solid waste management business, all big cities have successively issued solid waste handling charges levied administrative measures in accordance with the provisions of Regulations of Administration on City Appearance and Environmental Health and Measures of Hubei Province for Administration of Urban Environmental Hygiene issued by the State Council. All units and individuals who produce solid waste within urban planned districts should pay solid waste handling charges according to these rules. In short, the current state of solid waste handling in our country needs rapid improvement.

\section{Hazardous Solid Waste Management in US}

The US is one of the initial countries who pay special attention to implement hazardous waste management. It has a relatively mature management system which is worth studying and can serve as a reference for our management. The US EPA was originated in 1970. It issued Law on Resource Conservation and Recycling in 1976 and revised it 10 years later. The management proposal formulated in this law includes:

\section{Hazardous Solid Waste Management}

\section{Hazardous Waste Tracking System}

Hazardous waste management has proposed the concept of "from cradle to tomb". The production of hazardous waste is the "cradle" and treatment, storage, and disposal factories (TSD) are the "tomb". The Law stipulates that in the whole process of waste production, transportation and TSD, there should be unified hazardous waste list to be able to trace back, which is monitored by the federal as well as state EPA. It also formulates that waste producer should make analysis of the waste itself and the underground water and TSD is responsible for the analysis and supervision of others.

\section{Necessary Conditions of TSD Facilities}

In the late 1980s, there were thousands of TSD facilities which retrieved hazardous waste in the 
US, which are in the restraint of RCRA (most boring to most people). Those facilities contain incineration, dehydration and solid waste lantern facilities as well as landfills, surface aquifer and underground water injection wells.

\section{Superfund Programme}

The State Council of US has promulgated Comprehensive Environmental Response Compensation and Liability Act which requires to clean up the polluted hazardous waste sites. It sets up a hazardous substance response trust fund so as to be called "Superfund". These trust funds come from the tax imposed on the manufacturers who make use of crude oil and chemical materials as well as environmental tax levied by the administration. The enterprises should first draw up a schedule concerning the reduction of hazardous waste production refrained from responsibilities on later compliment of waste sites. The insurance industry plays an important role in the compulsory internalization process of external costs. If the insurance market operates properly, those high-risk hazardous waste producers will pay relatively higher insurance expenses functioning as responsibility deposits than low-risk producers or managers, thus forming a economic stimulation to decrease handling fees and insurance expenses. The enterprises will select a smart way and responsibility deposit standard to balance the marginal cost and marginal benefit. From the analysis above, we can see that the internalization process of exterior costs compelled by the government is effectively carrying on.

\section{Deposit-Refund Scheme}

Deposit-refund scheme's function will be maximized if waste is improperly disposed ending up with serious consequences. When controlled materials converge into producing process, the producer or the initial user should pay a certain amount of deposit. In principle, the number of the deposit is based on the social cost caused by illegal management. The responsibility of proper management is transferring among the producer, wholesaler and distributor during the process of production and consumption. This transferring mechanism will be going on until the consumer put the product (or its pack) to the designated recycling centre in order to be reused or properly managed.

\section{Suggestions on Solid Waste Management System Improvement In The Twelfth Five-year Plan Period}

During the twelfth five-year plan period, we have reinforced the need to carry on scientific and sustainable development in our planning. In order to construct an environment-friendly society and establish ecological civilization, we should make greater effort to conserve our environment, which also represents the need of social development. Proper exploitation and utilization of environmental resources should be in line with a scientific and effective management of sold waste for the purpose of creating virtuous circle. If we fail to act now, it would cost more later and we may even repeat the environmental pollution cases happened in industrialized countries. To avoid more historical tragedies like Love Canal accident, China should improve our management on solid waste. Here are my suggestions:

Advertise the harmfulness of solid waste to the whole social community and insert the concept of environmental protection into all individuals' minds. To form a good habit of reducing the emissions, reasonable emissions and orderly emissions.

Foster the establishment of hazardous solid waste management system to manage in accordance with specific department and sector and at the same time build up monitoring mechanism. 
Improve legislative system as an guarantee. To assess and revise Environmental Protection Act, Law of Prevention and Control of Atmospheric Pollution and Law on Prevention and Control of Solid Waste Pollution so as to be more scientific, maneuverable and adaptable to new circumstances.

Increase the funds in solid waste management departments.

Industries aiming to make scientific development in the field of recycling and reusing waste should be promoted through such measures as financial allocations, taxation preference and so on.

\section{References}

[1] Lan Zhilong, Sun Chunxia, American Public Policy in Action, Beijing:China Renmin University Press, 2007, 10: 304-318

[2] She Lian, On Enterprise Forewarning Management, Hebei Science and Technology Press, 1999

[3] Portney, Paul R.and Stavins Robert N.: Public Policies for Environmental Protection, Shanghai: Shanghai Joint Publishing Company and Shanghai People's Publishing House (SPPH), 2004

[4] Ortolano, Leonard. Environmental Regulation and Impact Assessment, Beijing: Chemical Industry Press, 2004

[5] Zhang Yijun, A handbook of the United States government, Beijing: Military Publishing Hou se of Friendship and Literature, 2000

[6] Department of Total Pollutants Control of State Environmental Protection Administration, Basel Convention on the Control of Transboundary Movements of Hazardous Wastes and Their Disposal.Beijing: Chemical Industry Press, 2002 